を示すと第 2 図のごとくである。第 2 図の関 倸注第 1 図のそれと全く同じである。以上の 実験結果から分別 PVA 皮膜㧍よび未分別 PVA 皮膜ともに, 易溶性部分を除去した皮 膜が熱処理において，特異な挙動を示さない ことが明らかである。

\title{
文献
}

1) 桜田, 温品, 曾根：高化, 12, 514(1955)

2) 桜田, 温品, 篦根：高化, 12, 509(1955)

3）桜田, 温品, 霄根： 高化, 12, 513(1955)

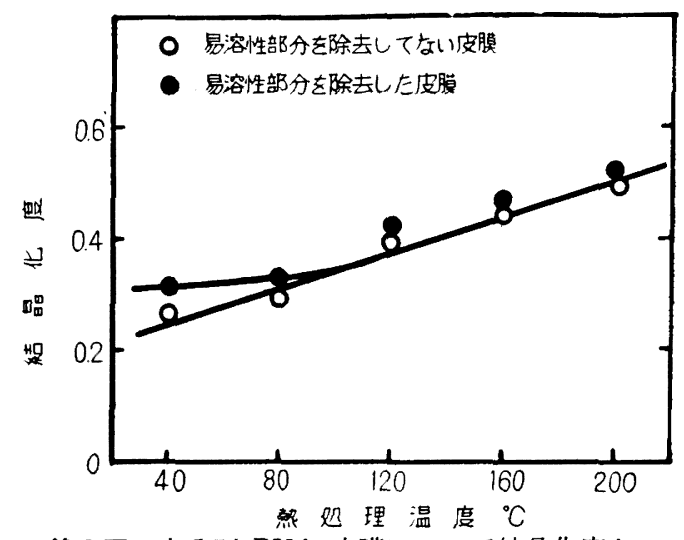

策 2 図分別 PVA 皮膜について結晶化度と 熱処理温度との関倸

\section{Studies on the Swelling of Polyvinyl Alcohol}

\section{Influence of the Removal of Soluble Parts on the Effect of the Heat Treatment of Polyvinyl Alcohol Films}

\section{By Yasuo Sone and Ichiro Sakurada}

Films were prepared from a fractionated polyvinyl alcohol of DP 1288, subjected to a light heat treatment at $40^{\circ} \mathrm{C}$ for 10 minutes and then immersed in water at $30^{\circ} \mathrm{C}$ for the removal of water soluble parts of films. The extracted films were then air dried and subjected to heat treatment at $40,80,120,160$ and $200^{\circ} \mathrm{C}$ for 10 minutes. Original films were also similary treated and the swelling, solubility and density of the two series of films were compared. In the case of heat treatment at lower temperature, there was a distinct difference between the two series. Extracted films showed lower swelling and higher density and crystallinity. Similar experiments were also carried out with an unfractionated polyvinyl alcohol of DP 1550 to obtain similar results.

第 6 報 ポリビニルアルコール皮膜の水溶性部分および不溶性部分から 彆造した皮膜の膨潤性の比較

(1956 年 7 月 23 日受理)

曾 根康夫·桜田一 郎

要 旨 平均重合度 720 の分別ポリビニルアルコール(PVA)からつくった皮膜, およびその皮膜の水 溶性部分ならびに不溶性部分から製造した 3 種類の皮膜について, 種々の温度で熱処理してそのものの膨潤 度, 溶解度, 結晶化度を測定して比較した。低温熱処理の場合は膨潤度および溶解度は皮膜の種類によって 
明らかに異なる。これは各々の皮膜を形成する PVA 分子に本質的な結晶性の相違があるからでなく，単に 重合度の違いによって起ったものと思われる。このことから PVA 皮膜の水溶性部分と不溶性部分は, PVA 分子の本質的な性質の相違によって生ずるのでなく，同じ分子であっても皮膜形成の過程で水溶性部分もま た同時に不溶性部分も形成することがわかる。

\section{I. 緒 言}

PVA 皮膜が膨潤に際して部分的に溶解する場合，溶解は分子のいずれの部分も結晶領域に足 場を持たないような分子によって起ることが明らかである゙1”。た不溶性の膨潤体は結晶領域に 足場を持った分子からなっている。したがって PVA 皮膜のそのような溶解部分を形成する分子 はそれ自身難結晶性であるのかどうか，あるいは不溶性部分を形成する分子はそれ自身本質的に 結晶化しやすいのかどうかを確かめることが本実験の目的である。このために，分別 PVA 皮膜 の多量の水による膨潤を行い，その際の溶解部分からつくった皮膜および不溶部分の膨潤体を再 溶解してつくった皮膜, さらに比較のため可溶性物を除去しない元の皮膜を種々の温度で熱処理 して, そのものの膨潤度, 溶解度, 比重, 結晶化度を測定して比較検討した。

\section{II. 実験}

試料の作製

a）可溶性物を除去しない元の皮膜（原皮膜）平均重合度 720 の分別 PVA を原料にして常法 で厚さ約 $0.2 \mathrm{~mm}$ の皮膜をつくった。皮膜は $30^{\circ} \mathrm{C}$ で塩化カルシウムデシケーターで 1 週間乾燥 した。

b) 溶解性部分からつくった皮膜（溶解物皮膜） 原皮膜 $1.3 \mathrm{~g}$ を $30^{\circ} \mathrm{C}, 300 \mathrm{cc}$ の蒸溜水に 3 日間浸洁膨潤させた。この間連続㩭排した。原皮膜は膨潤に伴って $20.8 \%$ 溶解した。膨潤体を 沪別し, 沪液を加熱濃縮し, 後風乾して常法により皮膜をつくり，さらに塩化カルシウムデシケ ーターで乾燥した。この皮膜の PVA の平均重合度は540であり，原皮膜より著しく低い。厚さ は約 $0.2 \mathrm{~mm}$ である。

c） 不溶性部分からつくった皮膜（不溶解物皮膜）原皮膜の不溶解性部分すなわち膨潤体を乾 燥せず蒸溜水に加熱溶解し，常法で皮膜をつくり，デシケーター乾燥をした。この皮膜の PVA の平均重合度は 770 であり，原皮膜よりわずかに高い。厚さは約 $0.2 \mathrm{~mm}$ である。

d) 熱処理 以上 3 種類の乾燥皮膜を $40,80,120,160,200^{\circ} \mathrm{C}$ で各 10 分間熱処理して試料と した。

膨潤度, 溶解度, 比重, 結晶化度の測定は常法²による。

\section{III. 実験結果ならびに考察}

原皮膜, 溶解物皮膜, 不溶解物皮膜の種々の温度で熱処理したものの膨潤度その他の测定値を 
第 $1,2,3$ 表に示す。

第 1 表原 皮膜

\begin{tabular}{l|c|c|c|c|c}
\hline \multicolumn{1}{c|}{ 試 料 番 号 } & 1 & 2 & 3 & 4 & 5 \\
\hline 熱処理温度 ${ }^{c} \mathrm{C}$ & 40 & 80 & 120 & 160 & 200 \\
膨潤度 & 4.84 & 3.68 & 1.42 & 0.28 & 0.26 \\
比重 & 1.2838 & 1.2882 & 1.2950 & 1.3037 & 1.3064 \\
結晶化度 & 0.24 & 0.26 & 0.36 & 0.46 & 0.50 \\
溶解度(分率) & 0.389 & 0.324 & 0.026 & 0 & 0 \\
\hline
\end{tabular}

第 2 表 溶 解物皮膜

\begin{tabular}{l|c|c|c|c|c}
\hline \multicolumn{1}{c|}{ 試 料 番 号 } & 6 & 7 & 8 & 9 & 10 \\
\hline 熱処理温度 ${ }^{c} \mathrm{C}$ & 40 & 80 & 120 & 160 & 200 \\
膨潤度 & 6.00 & 3.90 & 1.43 & 0.27 & 0.20 \\
比重 & 1.2995 & 1.3001 & 1.3087 & 1.3149 & 1.3149 \\
結晶化度 & 0.24 & 0.28 & 0.37 & 0.43 & 0.39 \\
溶解度(分率) & 0.508 & 0.412 & 0.118 & 0 & 0 \\
\hline
\end{tabular}

第 3 表 不溶解物皮膜

\begin{tabular}{l|c|c|c|c|c}
\hline \multicolumn{1}{c|}{ 試 料 番 号 } & 11 & 12 & 13 & 14 & 15 \\
\hline 熱処理温度 ${ }^{c} \mathrm{C}$ & 40 & 80 & 120 & 160 & 200 \\
膨潤度 & 4.62 & 3.42 & 1.42 & 0.28 & 0.24 \\
比重 & 1.2246 & 1.2882 & 1.2946 & 1.3012 & 1.3065 \\
結晶化度 & 0.28 & 0.33 & 0.47 & 0.54 & 0.53 \\
溶解度(分率) & 0.304 & 0.262 & 0.024 & 0 & 0 \\
\hline
\end{tabular}

第 1〜3 表から各皮膜の膨潤度と熱処理温 度との関倸を示すと第 1 図のごとくである。 第 1 図により各皮膜について膨潤度と熱処理 温度との関倸とともに，各熱処理温度での膨 潤度が皮膜の種類によっていかに違うかもわ かる。第 1 図によれば $120^{\circ} \mathrm{C}$ 以下の低温熱処 理では, 膨潤度は皮膜の種類によって明らか に異なり，溶解物皮膜が最も膨潤性が大であ り，ついで原皮膜，不溶解物皮膜の順である。 しかし $120^{\circ} \mathrm{C}$ 以上の高温で熱処理した場合 には，すでに皮膜の種類による影響は認めら

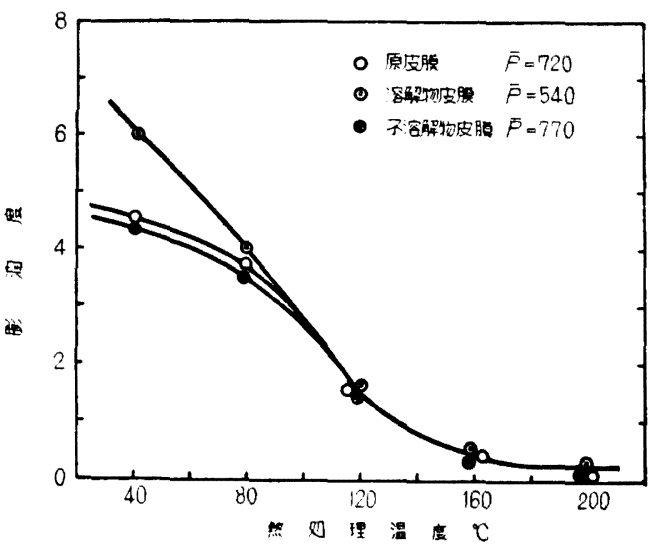

第 1 図種類を異にする皮膜について膨潤度と 熱処理温度との関係 


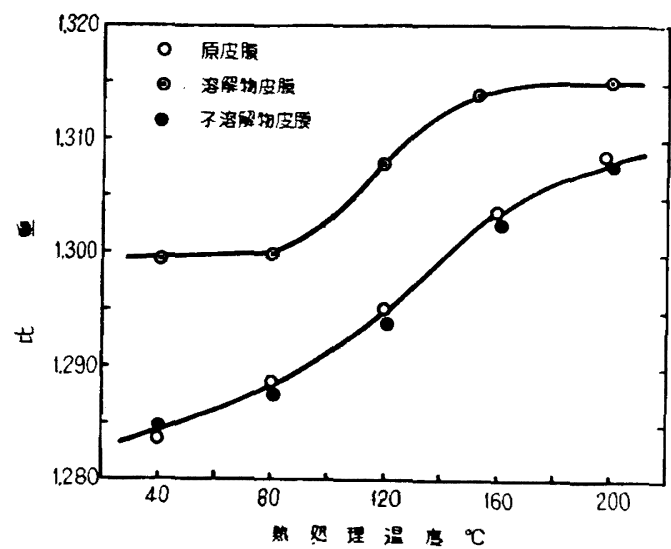

第 2 図種類を巽にする皮膜について比重と熱処 理温度との関倸

れない。ついで第 2 図に各皮膜について比重と 熱処理温度との関倸を示した。第 2 図では各皮 膜とも比重は熱処理温度によって S 字型の関倸 で変化するが, 同じ熱処理温度に扝いては溶解

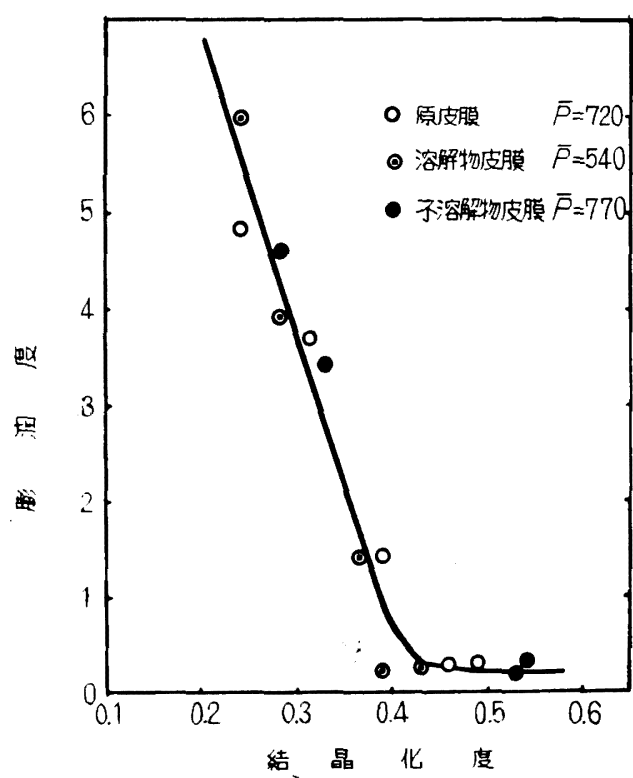

第 3 図 種稹を異にする皮膜について膨潤度と 結晶化度との関倸

物皮愺が特に高い比重を示す。原皮膜, 不溶解物皮膜は比重の上では全然違いはない。以前に分 別 PVA $\bar{P}=708$ の皮膜の比重を測定した ${ }^{2)}$ が, そのときの值と今回の原皮膜および不溶解物皮 膜の比重とがよく一致している。このことは分別 PVA 皮膜の比重測定に良好な再現性があり， 同時に不溶解物皮膜の比重は若干の重合度の相違を無視すれば，特異性がないわけである。また 溶解物皮膜の高い比重は絬晶化度が高いことによるものでないことをX線カウンターで結晶化度 を測定して確認した。溶解物皮膜の比重の特異的に高い原因は検討中である。ついで第 3 図に種 々の温度で熱処理された各種皮膜の膨潤度と $\mathrm{X}$ 線カウンター法で求めた結晶化度との関係を示 す。第 3 図では皮膜の種類および熱処理温度の相違にかかわらず各プロットは大体 1 本の曲線に のる。分別 PVA 皮膜の膨潤度が, 重合度および熱処理温度の相違にかかわらず, 結晶化度と 1 本 の曲線関倸で与えられることは，われわれがすでに明らかにしたところである2)。したがって第 3 図においては皮膜の種類の影響はむしろ，重合度の影響とみなされる。すなわち溶解物皮膜は $\bar{P}=540$ の分別 PVA 皮膜, 原皮膜は $\bar{P}=720$, 不溶解物皮膜は $\bar{P}=770$ のそれぞれ分別 PVA 皮膜 の挙動をしていると思われる。このことはさらに次の点からも確認できる。以前にわれわれは平 均重合度の広く異なる分別 PVA 皮膜について, 膨潤度と平均重合度の関係を求めたが2), その 関倸曲線の内拆によって, 各皮膜の PVA の平均重合度に相当する分別 PVA の膨潤度を求める と以下のごとくである。ただし $40^{\circ} \mathrm{C}$ 熱処理の場合である。 $P=540, Q=6.7, \bar{P}=720, Q=5.6$, $\bar{P}=770, Q=5.5$ 。これに対し $40^{\circ} \mathrm{C}$ 熱処理をした溶解物皮膜の膨潤度 $Q=6.00$, 原皮膜の $Q=4.84$ 
不溶解物皮膜の $Q=4.62$ である。分別 PVA の関係曲線の内拆によって求めた膨潤度と若干の 違いがあるが，皮膜製造条件などの影響を考虑すれば，むしろ良好なる一致と思われる。したが って皮膜の種類による膨潤度の違いは, 単に皮膜を形成する PVA の重合度の違いによって生ず るものと思われる。これと全く同じことが溶解度に対しても認められる。たとえば, $40^{\circ} \mathrm{C}$ およ び $80^{\circ} \mathrm{C}$ で熱処理した各皮膜の溶解度と, 以前にわれわれが求めた分別 PVA 皮膜における溶解 度と平均重合度の関係曲線 ${ }^{2)}$ の内拆で，本実験の各皮膜に相当する平均重合度の分別 PVA 皮膜 の溶解度を求めて比較すると第 4 表のごとくである。

第 4 表では本実験の各皮膜の溶解 度はそれを形成する PVA と同一重 合度の別実験の分別 PVA 皮膜の溶 解度と変るところがない。

以上の実験結果から低温熱処理の 際に認められる溶解物皮膜, 原皮膜, 不溶解物皮膜相互間の膨潤度, 溶解 度, 結晶化度の相違はそれぞれの皮
第 4 表 本実験の各皮膜とそれの重合度に相当する分別 PVA 皮膜の溶解度の比較

\begin{tabular}{l|l|l}
\hline \hline & $40^{\circ} \mathrm{C}$ 熱処理 & $80^{\circ} \mathrm{C}$ 熱処理 \\
\hline 溶解物 皮 膜 $(\bar{P}=540)$ & 0.508 & 0.400 \\
原 皮 膜 $(\bar{P}=720)$ & 0.390 & 0.310 \\
不溶解物 皮膜 $(\bar{P}=770)$ & 0.340 & 0.260 \\
分別 PVA 皮膜 $(\bar{P}=540)$ & 0.50 & 0.38 \\
分別 PVA 皮膜 $(\bar{P}=720)$ & 0.40 & 0.28 \\
分別 PVA 皮膜 $(\bar{P}=770)$ & 0.36 & 0.24 \\
\hline
\end{tabular}

膜を形成する PVA 分子の本質的な結晶化能の相違によると見るよりは，むしろ重合度の違いに よる影響と思われる。また分別 PVA 皮膜の水溶性部分あるいは不溶性部分は特定の性質の分子 によってできるのでなく，同じ分子であっても，皮膜製造過程で常に非結晶部分と結晶部分が同 時にできる結果生ずるのであろう。

付 毁： 結晶化度の $\mathrm{X}$ 線図的測定は温品恭彦氏によるものである。厚く感謝する次第である。

\title{
女献
}

1) 桜田, 温品, 曾根：高化, 12, 510(1955)

2) 桜田, 温品, 篔根：高化, 12, 506(1955)

\section{Studies on the Swelling of Polyvinyl Alcohol}

\section{Swelling of Films Prepared from Water-Soluble and Insoluble Parts of Polyvinyl Alcohol Films}

By Yasuo Sone and Ichiro Sakurada

\begin{abstract}
A fractionated polyvinyl alcohol of DP 720 was used as a starting substance and according to the method given in the previous report separated into water-soluble and insoluble parts. DP's of the water soluble and insoluble parts were 540 and 770 respectively. Films were prepared from these two kinds of polyvinyl alcohol and subjected to heat treatment to compare swelling, solubility and crystallinity. In the case of heat treatment at lower temperature, there was a distinct difference between the two. Films from water soluble part showed higher swelling and lower density and crystallinity. It was attributed not to the difference of molecular structure but to the difference of molecular weight.
\end{abstract}

